\title{
PREDIKSI HARGA EMAS DUNIA DI MASA PANDEMI COVID-19 MENGGUNAKAN MODEL ARIMA
}

\author{
Dara Puspita Anggraeni ${ }^{1}$, Dedi Rosadi², Hermansah ${ }^{3}$, Ahmad Ashril Rizal ${ }^{4}$ \\ ${ }^{1}$ Universitas Nahdlatul Wathan Mataram, ${ }^{2}$ Universitas Gadjah Mada Yogyakarta, ${ }^{3}$ Universitas Riau Kepulauan, \\ ${ }^{4}$ STMIK Syaikh Zainuddin NW Anjani Lombok timur \\ e-mail: ${ }^{1}$ darapuspitaanggraeni40@gmail.com, ${ }^{2}$ dedirosadi@ gadjahmada.edu, ${ }^{3}$ hermansah@mail.ugm.ac.id, \\ 4ashril.rizal@gmail.com
}

\begin{abstract}
Abstrak
Penelitian ini bertujuan memodelkan serta memprediksi harga emas dunia di masa pandemi COVID-19. Penelitian ini juga hanya memasukkan nilai masa lampau dari harga emas dunia tanpa adanya pengaruh faktor eksogen(independen) pada model. Model yang dipergunakan adalah model Autoregressive Integrated Moving Average (ARIMA). Adapun data yang dipergunakan pada permodelan sebanyak 240 data observasi dimana data merupakan data bulanan harga emas dunia bulan Agustus 2000 hingga Juli 2020. Model terbaik untuk harga emas dunia ini adalah $\operatorname{ARIMA}(0,1,1)$ dengan nilai Mean Absolute Percentage Error (MAPE) sebesar 3,70\%. Hasil prediksi harga emas dunia untuk bulan Agustus 2020 hingga Januari 2021 berturut-turut adalah sebesar 1930,046; 1945,651; 1961,381; 1977,240; 1993,227; 2009,343 US \$/Troy Ons emas. Prediksi ini menunjukkan tren naik dengan rata-rata peningkatan selama periode tersebut (Agustus 2020-Januari 2021) sebesar15,8594 US\$/Troy ons per bulannya.
\end{abstract}

Kata kunci: Harga Emas, COVID-19, ARIMA, Prediksi

\begin{abstract}
This research aims to model and predict the world gold price during the COVID-19 pandemic. This research only includes the past values of world gold prices without the influence of exogenous (independent) factors on the model. The model used in this research is the Autoregressive Integrated Moving Average (ARIMA). The data used in the modeling are 240 observational data which were the monthly data on world gold prices from August 2000 to July 2020. The best model for this world gold price is ARIMA $(0,1,1)$ with a Mean Absolute Percentage Error (MAPE) value of 3.70\%. The prediction results of the world gold price from August 2020 to January 2021 are 1930,046 respectively; 1945,651; 1961,381; 1977,240; 1993,227; 2009,343 US \$ / Troy Ounce of gold. This prediction shows an upward trend with the average increase 15,8594 US \$ / Troy ounce per month during that period (August 2020January 2021).
\end{abstract}

Keywords: Gold Price, COVID-19, ARIMA, Prediction

Prediksi Harga Emas Dunia Di Masa Pandemi.../Anggraeni, D.P., Rosadi D., Hermansah, dan Rizal A.A. |71 


\section{PENDAHULUAN}

Investasi diminati oleh sebagian besar orang di dunia. Investasi atau penanaman modal sering sekali dilakukan dengan tujuan mendapatkan keuntungan di masa depan. Jenis investasi yang paling diminati di saat ini adalah emas, saham, obligasi dan properti. Tiap jenis investasi ini memiliki keuntungan dan risiko yang berbeda-beda. Menurut Warsono (2010) pada umumnya investasi pada aset riil mempunyai nilai satuan yang relatif besar dan mempunyai likuiditas relatif rendah, sedangkan aset keuangan mempunyai nilai satuan yang relatif kecil dan pada umumnya mempunyai likuiditas yang tinggi. Investasi yang relatif mudah untuk dilakukan saat ini adalah pada aset keuangan. Salah satu prinsip dalam berinvestasi adalah higher return higher risk. Suatu investasi dengan pengembalian diharapkan sangat tinggi, maka risiko yang dihadapi oleh investor juga sangat tinggi. Sebaliknya, jika angin berinvestasi pada aset keuangan dengan risiko rendah, maka pengembalian yang diharapkan juga rendah(Yulianti \& Silvy, 2013).

Emas atau logam mulia menjadi jenis investasi yang sering kali disebut sebagai investasi aman dibandingkan jenis instrumen investasi lannya. Investasi emas dikatakan mudah karena emas ini, tidak harus dimiliki seseorang yang mempunyai penghasilan besar ataupun seseorang yang mempunyai jabatan khusus. Emas ini juga dapat dimanfaatkan oleh siapapun dari berbagai macam kalangan masyarakat. Selain mudah, investasi emas juga merupakan salah satu investasi yang sangat menguntungkan karena emas merupakan satu-satunya logam mulia yang harga jualnya tidak terpengaruh oleh inflasi yang terjadi. Dapat dibuktikan sebagai contoh, satu koin dinar yang memiliki berat $\pm 4,25$ gram misalnya setara dengan harga 1 ekor kambing pada masa Rasulullah SAW, dan sampai sekarang pun masih berlaku seperti itu karena emas tidak terpengaruh oleh inflasi. Yang berubah hanyalah daya beli emas dengan uang kertas seperti Rupiah yang semakin lama semakin menurun.
Selain itu seperti yang kita ketahui bahwasanya harga emas cenderung terus menerus mengalami kenaikan setiap tahunnya(Fauziah \& Surya, 2016) terlebih lagi disaat pandemi COVID-19 yang menelan korban sebanyak 15.785.641 kasus dan 640.016 kematian per 26 Juli 2020 (WHO, 2020b) sehingga sangat mengganggu sektor kesehatan juga sektor perekonomian, termasuk dunia investasi saham (Baker et al., 2020) ditunjukkan dengan nilai indeks saham gabungan yang menurun di beberapa negara yang mengakibatkan beralihnya investasi yang diminati oleh calon investor dari bentuk saham ke dalam bentuk investasi emas(Ji et al., 2020). Hal ini diperkuat oleh hasil penelitian yang telah dilakukan oleh $\mathrm{Ji}$, Zhang dan Zhao ini dengan melakukan analisa pada beberapa jenis investasi diluar saham sebagai investasi teraman selama pandemi Covid-19, diperoleh hasil yang menunjukkan emas sebagai investasi teraman(Ji et al., 2020). Oleh karenanya sangat menarik untuk memodelkan harga emas dunia yang dapat bermanfaat baik bagi para praktisi maupun peneliti.

Pada penelitian ini peneliti akan menggunakan model ARIMA dikarenakan model ini telah terbukti cocok untuk memodelkan serta memprediksi harga emas dunia. Penelitian sebelumnya diantara lain dilakukan oleh Abdullah (2012), Khan (2013), Bandyopadhyay (2016) dan Yang (2019). George Box dan Gwilym Jenskin adalah penemu model ARIMA pada tahun 1976. Box dan Jenkins menggunakan model-model ARIMA untuk deret waktu satu variable (univariate). Model ARIMA $(p, d, q)$, dimana $p$ menyatakan orde dari proses autoregressive (AR), $d$ menyatakan pembeda (differencing) dan $q$ menyatakan orde dari proses moving average (MA). Dasar dari model ARIMA dilakukan dengan empat tahap strategi pemodelan yaitu identifikasi model, penaksiran parameter, pemeriksaan diagnostik dan prediksi (Rosadi, 2011).

Adapun tujuan dari penelitian ini adalah untuk memodelkan serta memprediksi harga emas dunia di masa mendatang dengan akurat. 


\section{METODE}

\section{Tinjauan Referensi}

Emas merupakan safe haven dikarenakan ketersediaannya yang langka, banyak diminati dan sangat berharga secara intrinsik terlebih selama masa pandemi COVID-19 (Ji et al., 2020). Penelitian tentang model dan prediksi harga emas dunia di masa pandemi COVID-19 belum banyak dilakukan sehingga peneliti tertarik untuk melakukan penelitian ini dengan salah satu tujuannya adalah membantu praktisi(misalkan calon investor) dalam pengambilan keputusan investasi emas.

Penelitian tentang prediksi harga emas dunia menggunakan model ARIMA merujuk pada penelitian terdahulu dilakukan oleh Guha Bandyopadhyay yang memperoleh kesimpulan bahwa prediksi menggunakan model ARIMA sangat akurat digunakan untuk prediksi jangka pendek (Bandyopadhyay, 2016). ARIMA juga sangat baik menggambarkan data yang fluktuatif (Abdullah, 2012), dan cocok digunakan untuk menggambarkan serta meramalkan pergerakan harga emas dunia (Khan, 2013; Yang, 2019)

\section{Metode Analisis}

\section{Time Series Data}

Time Series (Runtun waktu) data yakni jenis data yang dikumpulkan menurut urutan waktu dalam suatu rentang waktu tertentu. Jika waktu dipandang bersifat diskrit (waktu dapat dimodelkan bersifat kontinu), maka frekuensi pengumpulan selalu sama (equidistant). Dalam kasus diskrit, frekuensi dapat berupa misalnya detik, menit, jam, hari, minggu, bulan atau tahun. Model yang digunakan adalah model-model time series, yang menjadi fokus dari perkuliahan ini (Rosadi, 2006).

\section{Kestasioneran Data}

Stasioneritas merupakan suatu keadaan jika proses pembangkitan yang mendasari suatu deret berkala didasarkan pada nilai tengah konstan dan nilai varians konstan. Dalam suatu data kemungkinan data tersebut tidak stationer hal ini dikarenakan mean(rata-rata) tidak konstan atau variannya tidak konstan sehingga untuk menghilangkan ketidakstasioneran terhadap mean, maka data tersebut dapat dibuat lebih mendekati stasioner dengan cara melakukan penggunaan metode pembedaan atau differencing. Perilaku data yang stasioner antara lain tidak mempunyai variasi yang terlalu besar dan mempunyai kecenderungan untuk mendekati nilai rataratanya, dan sebaliknya untuk data yang tidak stasioner(Gujarati, 2004).

1. Stasioner dalam variasi

Pada data yang tidak stasioner dalam variasi dapat dilakukan transformasi untuk membuat data tersebut stasioner.Box dan Cox pada tahun 1964 memperkenalkan transformasi pangkat (power transformation) sebagai berikut:

$$
Z_{t}^{\prime}=\left\{\begin{array}{l}
\frac{Z_{t}^{\lambda}-1}{\lambda}, \lambda \neq 0 \\
\ln \left(Z_{t}\right), \lambda=0
\end{array}\right.
$$

Dengan $Z_{t}$ adalah deret waktu periode ke-t dan $\lambda$ adalah parameter transformasi.

2. Stasioner dalam rata-rata

Data yang tidak stasioner dalam ratarata dapat distasionerkan melalui proses differensing. Pengujian hipotesis yang yang sering digunakan untuk melakukan pengecekan kestasioneran data runtun waktu dalam rata-rata adalah uji Augmented Dickey-Fuller (ADF). Uji ini merupakan salah satu uji yang paling sering digunakan dalam pengujian stasioneritas dari data, yakni dengan melihat apakah di dalam model terdapat unit root atau tidak(Rahmawati et al., 2019).

Pengujian dilakukan dengan menguji hipotesis $H_{0}: \rho=0$ (terdapat akar unit) dalam persamaan regresi

$$
\begin{aligned}
\Delta Y_{t}=\alpha+\delta t & +\rho Y_{t-1} \\
& +\sum_{\substack{j=1 \\
k}} \emptyset_{j} Y_{t-j} \\
& +e_{t}
\end{aligned}
$$

Hipotesis nol ditolak jika nilai statistik uji ADF memiliki nilai kurang (lebih negatif) dibandingkan dengan nilai daerah kritik. Jika hipotesis nol ditolak, data bersifat stasioner (Rosadi, 2011).

\footnotetext{
Prediksi Harga Emas Dunia Di Masa Pandemi..../Anggraeni, D.P., Rosadi D., Hermansah, dan Rizal A.A. | 73
} 


\section{Fungsi Autokorelasi dan Fungsi Autokorelasi Parsial}

Tahap identifikasi model pada model data runtun waktu dibutuhkan hasil perhitungan fungsi autokorelasi dan fungsi autokorelasi parsial. Adapun perhitungannya adalah sebagai berikut:

1. Fungsi Autokorelasi (Autocorrelation Function/ACF)

Konsepsi autokorelasi setara (identik) dengan korelasi Pearson untuk data bivariat. Menurut Mulyana (2004) persamaan koefisien autokorelasi $\rho_{k}$ adalah:

$$
\rho_{k}=\frac{\sum_{t=1}^{n-k}\left(Z_{t}-\bar{Z}\right)\left(Z_{t+k}-\bar{Z}\right)}{\sum_{t=1}^{n}\left(Z_{t}-\bar{Z}\right)^{2}}
$$

\section{Keterangan:}

n: jumlah observasi

k: selisih waktu (lag)

$Z_{t}$ : adalah data pada waktu- $t$

$Z_{t+k}$ : adalah data pada waktu ke- $\mathrm{t}+\mathrm{k}$

$\bar{Z}$ : rata-rata dari $Z_{t}$

Plot (grafik) ACF yang menurun menjadi salah satu indicator data belum stasioner.

2. Fungsi Autokorelasi Parsial (Partial Autocorrelation function/PACF)

Nilai PACF dapat dihitung dengan cara sebagai berikut:

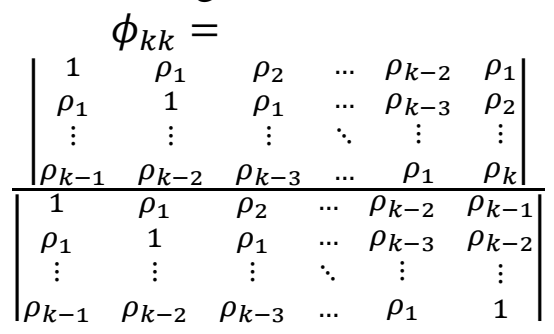

(Mulyana, 2004).

Keterangan: formula diatas merupakan perhitungan untuk PACF untuk lag $\mathrm{k}$ dan $\mathrm{j}=1,2,3, \ldots, \mathrm{k}$

\section{Model ARIMA}

Model AR(p) dan MA(q) merupakan model data runtun waktu stasioner dan saling berkebalikan, sehingga keduanya dapat digabungkan dengan cara dijumlahkan, dan model yang diperoleh dinamakan model autoregresi rata-rata bergerak, disingkat ARMA(p,q). Karena $\mathrm{AR}(\mathrm{p})$ dan MA(q) adalah model data runtun waktu stasioner, maka $\operatorname{ARMA}(p, q)$ juga model data runtun waktu stasioner. Jika data tidak stasioner, maka dapat distasionerkan melalui proses stasioneritas, yang berupa proses diferensi jika trendnya linier, dan proses linieritas dengan proses diferensi pada data hasil proses linieritas, jika trend data tidak linier (Mulyana, 2004). Model ARMA(p,q) untuk data hasil proses diferensi dinamakan model autoregresi integrated rata-rata bergerak disingkat $\operatorname{ARIMA}(p, d, q)$ dengan persamaan:

Bentuk umum dari persamaan model ARIMA:

$$
\begin{aligned}
& \left(1-\phi_{1} B-\cdots-\phi_{p} B^{p}\right)(1- \\
& B)^{d} Z_{t}=\mu+\varepsilon_{t}+\theta_{1} \varepsilon_{t-1}+ \\
& \cdots+\theta_{q} \varepsilon_{t-q}, \varepsilon_{t} \sim \operatorname{IID}\left(0, \sigma^{2}\right)
\end{aligned}
$$

dengan $B$ yang merupakan operator balik (backward), yakni $\left(B^{j} Z\right)_{t}=Z_{t-j}$ (Rosadi, 2011).

Persamaan diatas dapat pula dituliskan dalam bentuk:

$$
\begin{aligned}
& \left(1-\phi_{1} B-\cdots-\phi_{p} B^{p}\right)(1- \\
& B)^{d} Z_{t}=\mu+\left(1+\theta_{1} B+\right. \\
& \left.\cdots+\theta_{q} B^{q}\right) \varepsilon_{t}, \varepsilon_{t} \sim \operatorname{IID}\left(0, \sigma^{2}\right)
\end{aligned}
$$

\section{Prapemrosesan Data}

Dalam tahap awal dilakukan identifikasi model runtun waktu yang mungkin digunakan untuk memodelkan sifat-sifat data. Identifikasi secara sederhana dilakukan secara visual dengan melihat plot data, untuk melihat adanya tren, komponen musiman, nonstasioneritas dalam variasi dan lain-lain. Beberapa teknik prapemrosesan data yang umum dilakukan adalah membuang pencilan dari dalam data, penyaringan data dengan model/teknik statistika tertentu, transformasi data (seperti transformasi logaritma atau yang lebih umum transformasi Box-Cox), melakukan operasi deferens, detren (membuang tren), deseasonalize (membuang komponen musiman) dan lain-lain(Rosadi, 2011).

\section{Identifikasi Model Stasioner}

Bentuk model ARMA yang tepat dalam menggambarkan sifat-sifat data dapat ditentukan dengan plot sampel $\mathrm{ACF} / \mathrm{PACF}$ dengan sifat-sifat fungsi 
Tabel 1. Bentuk plot sampel ACF/PACF dari model ARMA

\begin{tabular}{|c|c|c|}
\hline Proses & Sampel ACF & Sampe PACF \\
\hline $\begin{array}{l}\text { White noise } \\
\text { (galat acak) }\end{array}$ & $\begin{array}{l}\text { Tidak ada yang melewati batas } \\
\text { interval pada } l a g>0\end{array}$ & $\begin{array}{l}\text { Tidak ada yang melewati batas } \\
\text { interval pada } l a g>0\end{array}$ \\
\hline $\mathrm{AR}(\mathrm{p})$ & $\begin{array}{l}\text { Meluruh menuju nol secara } \\
\text { eksponensial }\end{array}$ & $\begin{array}{l}\text { Di atas batas interval maksimum } \\
\text { sampai lag ke } p \text { dan di bawah batas } \\
\text { pada } \operatorname{lag}>p\end{array}$ \\
\hline MA(q) & $\begin{array}{l}\text { Di atas batas interval maksimum } \\
\text { sampai lag ke } q \text { dan di bawah batas } \\
\text { pada } \operatorname{lag}>q\end{array}$ & $\begin{array}{l}\text { Meluruh menuju nol secara } \\
\text { eksponensial }\end{array}$ \\
\hline $\operatorname{ARMA}(p, q)$ & $\begin{array}{l}\text { Meluruh menuju nol secara } \\
\text { eksponensial }\end{array}$ & $\begin{array}{l}\text { Meluruh menuju nol secara } \\
\text { eksponensial }\end{array}$ \\
\hline
\end{tabular}

ACF/PACF teoritis dari model ARMA. Rangkuman bentuk plot sampel ACF/PACF dari model ARMA diberikan pada tabel 1 (Rosadi, 2011).

\section{Penaksiran Parameter/Estimasi Model}

Estimasi dari model ARMA dapat dilakukan dengan metode Maksimum Likelihood Estimator (MLE), Least Square, Hannan Rissanen, metode Whittle dan lainlain(Rosadi, 2011).

\section{Pengujian Signifikansi Parameter}

Pengujian apakah koefisien hasil estimasi signifikan atau tidak dengan uji hipotesis:

- Uji konstanta pada model:

$$
\begin{aligned}
& H_{0}: \mu=0 \\
& H_{1}: \mu \neq 0
\end{aligned}
$$

$H_{0}$ diterima jika $-t_{\text {tabel }} \leq t_{\text {hitung }} \leq$ $t_{\text {tabel }}$, sebaliknya jika $t_{\text {hitung }} \leq-t_{\text {tabel }}$ atau $t_{\text {hitung }} \geq t_{\text {tabel }}$ maka $H_{0}$ ditolak dan $H_{1}$ diterima (parameter signifikan).

Adapun perhitungan statistik uji

$t_{\text {hitung }}=t=(\hat{\mu}-0) / S E(\hat{\mu})$

dan statistik tabel $t_{\text {tabel }}=t(d f=$ $n-1 ; \alpha=2,5 \%)$.

- Uji Parameter untuk model AR(p)

$$
\begin{aligned}
& H_{0}: \phi_{i}=0, i=1,2 \ldots, p \\
& H_{1}: \phi_{i} \neq 0, i=1,2 \ldots, p
\end{aligned}
$$

$H_{0}$ diterima jika $-t_{\text {tabel }} \leq t_{\text {hitung }} \leq$ $t_{\text {tabel }}$, sebaliknya jika $t_{\text {hitung }} \leq-t_{\text {tabel }}$ atau $t_{\text {hitung }} \geq t_{\text {tabel }}$ maka $H_{0}$ ditolak dan $H_{1}$ diterima (parameter signifikan).

Adapun perhitungan statistik uji

$$
t_{\text {hitung }}=t=\left(\widehat{\phi}_{l}-0\right) / S E\left(\widehat{\phi}_{l}\right)
$$

dan statistik tabel $t_{\text {tabel }}=t(d f=$ $n-1 ; \alpha=2,5 \%)$.

- Uji Parameter untuk model MA(q)

$$
\begin{aligned}
& H_{0}: \theta_{i}=0, i=1,2 \ldots, q \\
& H_{1}: \theta_{i} \neq 0, i=1,2 \ldots, q
\end{aligned}
$$

$H_{0}$ diterima jika $-t_{\text {tabel }} \leq t_{\text {hitung }} \leq$ $t_{\text {tabel }}$, sebaliknya jika $t_{\text {hitung }} \leq-t_{\text {tabel }}$ atau $t_{\text {hitung }} \geq t_{\text {tabel }}$ maka $H_{0}$ ditolak dan $H_{1}$ diterima (parameter signifikan).

Adapun perhitungan statistik uji

$$
t_{\text {hitung }}=t=\left(\widehat{\theta}_{l}-0\right) / S E\left(\widehat{\theta}_{l}\right)
$$

dan statistik tabel $t_{\text {tabel }}=t(d f=$ $n-1 ; \alpha=2,5 \%)$.

Pada formula diatas $\mathrm{n}$ adalah banyak data yang dipergunakan dalam membangun model. Jika terdapat koefisien yang tidak signifikan, koefisien/orde lag tersebut dapat dibuang dari model dan model diestimasi kembali tanpa mengikutkan orde yang tidak signifikan

\section{Pemeriksaan Diagnosis}

Jika model merupakan model yang tepat, data yang dihitung dengan model 
(fitted value) akan memiliki sifat-sifat yang mirip dengan data asli . Dengan demikian, residual yang dihitung berdasarkan model yang telah diestimasi mengikuti asumsi dari galat model teoritis, seperti sifat white noise, normalitas dari residual (walaupun asumsi ini dapat diabaikan, tidak sepenting asumsi white noise dari galat0 dan lain-lain. Untuk melihat apakah residual bersifat white noise, du acara bisa digunakan yakni:

Melihat apakah plot sampel $\mathrm{ACF} / \mathrm{PACF}$ yang terstandarisasi (residual dibagi estimasi deviasi standar residual) telah memenuhi sifat-sifat proses white noise dengan mean 0 dan variansi 1

Melakukan uji korelasi parsial, yakni dengan menguji hipotesis:

$H_{0}: \rho_{1}=\rho_{2}=\cdots=\rho_{k}, k<n$ (tidak terdapat korelasi serial dalam residual sampai lag $-k, k<n$ )

Uji ini dapat dilakukan dengan statistik uji Box-Pierce:

$$
Q=n \sum_{j=1}^{k} \hat{\rho}(j)^{2}
$$

Atau Ljung-Box:

$$
Q=n(n+) \sum_{j=1}^{k} \hat{\rho}(j)^{2} /(n-j)
$$

yang akan berdistribusi $\chi^{2}(k-(p+$ $q)), k>(p+q) . \quad$ Di $\quad \operatorname{sini} \quad \hat{\rho}(j)$ menunjukkan nilai sampel ACF residual pada lag-j, sedangkan $\mathrm{p}$ dan q menunjukkan orde dari model ARMA (p,q). Apabila hipotesis cek diagnostic ditolak, model yang telah diidentifikasi si atas tidak dapat digunakan dan selanjutnya model yang mungkin sesuai untuk data dapat diidentifikasi kembali(Rosadi, 2011).

\section{Pemilihan Model Terbaik}

Selanjutnya, dalam praktikan ada banyak model yang memenuhi pengujian diagnostic di atas. Untuk model terbaik, pilih model yang meminimalkan ukuran kriteria informasi, seperti Aike Information Criteria (AIC)

$$
\begin{array}{r}
A I C=n \ln \left(\hat{\sigma}_{\varepsilon}{ }^{2}\right)+ \\
2(p+q+1) \\
\hat{\sigma}_{\varepsilon}^{2}=S S E / n
\end{array}
$$

Dengan sum of squared error (SSE) yang akan diestimasi dari jumlahan kuadrat semua nilai residual. Akan tetapi diketahui untuk model autoregresif, kriteria AIC tidak memberikan orde $p$ yang konsisten sehingga untuk pembanding kita bisa menggunakan kriteria informasi lain, seperti Schwarzt Bayesian Information Criteria $(S B C)$

$$
S B C=n \ln \left(\hat{\sigma}_{\varepsilon}^{2}\right)+(p+q+1) \ln n
$$

Atau bentuk-bentuk kriteria informasi lain yang diusulkan di dalam literatur(Rosadi, 2011).

\section{Pengukuran Ketepatan Model Prediksi}

Dalam analisis runtun waktu, sering kali data dibagi menjadi dua bagian yang disebut data in sample, yakni data-data yang digunakan untuk memilih model terbaik dengan langkah-langkah pemodelan di atas dan data out sample, yakni bagian data yang digunakan untuk memvalidasi keakuratan prediksi dari model terbaik yang diperoleh berdasarkan data in sample. Model yang baik tentunya diharapkan model terbaik untuk penyesuaian (fitting) data in sample dan sekaligus model yang baik untuk prediksi dalam data out sample.

Beberapa ukuran kebaikan penyuaian atau prediksi dapat dikenalkan, seperti ukuran Mean Square Error (MSE), root of MSE (RMSE), Median atau Mean Absolute Deviation (MAD) dan lain-lain.

Jika $\quad Z_{1}, \ldots, Z_{n} \quad$ menyatakan keseluruhan data, data in sample dapat dinyatakan sebagai $Z_{1}, \ldots, Z_{m}, m<n$. Jika nilai hasil penyuaian disebut $\hat{Z}_{1}, \ldots, \hat{Z}_{m}, m<n$, MSE, RMSE dan MAD untuk data in sample didefinisikan sebagai (Rosadi, 2011):

$$
\begin{gathered}
M S E=\frac{\sum_{i=1}^{m}\left(Z_{i}-\hat{z}_{i}\right)}{n}, m<n \\
R M S E=\sqrt{\frac{\sum_{i=1}^{m}\left(Z_{i}-\hat{Z}_{i}\right)}{n}}, m<n \\
M A D=\frac{\sum_{i=1}^{m}\left|Z_{i}-\hat{Z}_{i}\right|}{n}, m<n
\end{gathered}
$$


Lalu menurut Aswi dan Sukarna(2006), pengukuran ketepatan model dapat menggunakan perhitungan Mean Absolute Percentage Error (MAPE) dengan formula sebagai berikut:

$$
\begin{aligned}
& \operatorname{MAPE} \\
& =\frac{\sum_{i=1}^{m}\left|Z_{i}-\hat{Z}_{i}\right|}{Z_{i}}, m \\
& <n
\end{aligned}
$$

Gambar 1 merupakan diagram alir metodelogi pemodelan Box-Jenkins.

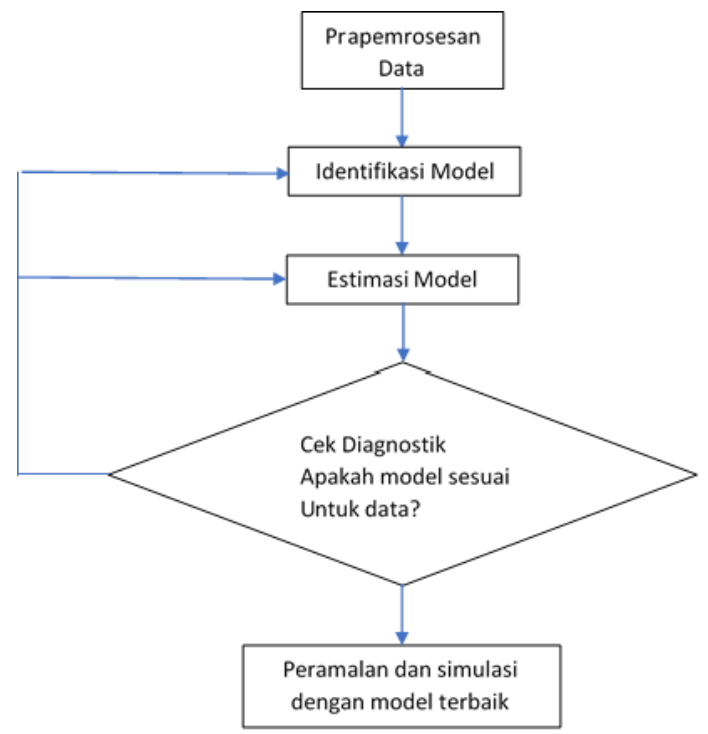

Gambar 1. Diagram alir metodelogi pemodelan Box-Jenkins(Rosadi, 2011).

\section{Pandemi COVID-19}

Pandemi COVID-19 yaitu masa dimana secara global terdapat penyakit menular yang disebabkan oleh virus korona yang baru ditemukan. Kebanyakan orang yang terinfeksi virus COVID-19 akan mengalami penyakit pernapasan ringan hingga sedang atau pulih tanpa memerlukan perawatan khusus. Manula dan mereka yang memiliki masalah medis mendasar seperti penyakit kardiovaskular, diabetes, penyakit pernapasan kronis dan kanker lebih berpeluang untuk terserang virus(WHO, 2020a). Pada saat ini, tidak ada vaksin atau perawatan khusus untuk COVID-19. Namun, ada banyak uji klinis yang sedang dilakukan untuk menemukan pengobatan untuk penyakit
Coronavirus(WHO, 2020a). Secara global per 26 Juli 2020 terdapat 15.785.641 kasus dan 640.016 kematian(WHO, 2020b).

\section{Data Penelitian}

Data yang digunakan dalam penelitian ini adalah data harga emas dunia per Agustus 2000 hingga Juli 2020 yang diperoleh dari website Yahoo Finance. Data yang diambil merupakan data bulanan yakti harga emas dunia tiap awal bulan sehingga total banyak data yang dipergunakan adalah 241 data. Satuan data harga emas dunia adalah US\$/Troy ons, dimana 1 Troy ons setara dengan 31,1035 gram.

\section{HASIL DAN PEMBAHASAN}

\section{Statistika Deskriptif}

Pembahasan akan diawali dengan membuat statistika deskriptif sebagai berikut:

Tabel 2. Statistika Deskriptif

\begin{tabular}{|l|l|}
\hline Rata-rata & 978,62 \\
\hline Standar Deviasi & 468,03 \\
\hline Nilai Minimum & 257,9 \\
\hline Nilai Maksimum & 1900,3 \\
\hline Skewness & $-0,14$ \\
\hline Kurtosis & $-1,29$ \\
\hline
\end{tabular}

Informasi yang diperoleh dari Tabel 2 adalah rata-rata harga emas dunia adalah US $\$ 978,62 /$ Troy ons, dimana data menyebar sebesar US $\$ 468,03 /$ Troy ons dari rata-rata. Harga emas dunia paling rendah sebesar US\$257,9/Troy ons dan paling tinggi sebesar US\$1916,8/Troy ons, dengan nilai kurtosis sebesar -1,29 maka dapat dikatakan kurva Platikurtik, merupakan distribusi yang memiliki puncak hampir mendatar (nilai keruncingan $<3$ ), serta skewness menunjukkan nilai negatif sebesar $-0,14$ atau nilai-nilai terkonsentrasi pada sisi sebelah kiri (terletak di sebelah kiri Mo), sehingga kurva memiliki ekor memanjang ke kiri, kurva menceng ke kiri atau menceng negatif untuk periode bulan Agustus 2000 hingga Juli 2020.

\section{Time Series Plot}

Prediksi Harga Emas Dunia Di Masa Pandemi..../Anggraeni, D.P., Rosadi D., Hermansah, dan Rizal A.A. 77 
Time series plot dapat digunakan untuk melakukan perkiraan kasar dari bentuk model yang mungkin sesuai untuk data dengan melihat plot data harga emas dunia.

Berdasarkan Gambar 2, diketahui bahwa harga emas dunia mengalami fluktuasi meskipun demikian secara garis besar terlihat bahwa harga emas dunia mengikuti pola tren naik. Hal ini menunjukkan emas sebagai investasi aman yang perlu diramalkan dengan model ARIMA.

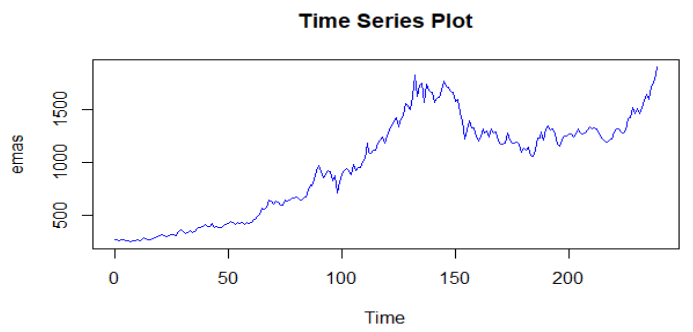

Gambar 2. Time Series Plot

\section{Metode Prediksi ARIMA}

Adapun tahapan untuk mendapatkan model ARIMA terbaik yaitu: prapemrosesan data, identifikasi model, estimasi model serta pengecekan diagnostik kesesuaian model dengan data serta pemilihan model terbaik.

Pada Gambar 2, terlihat data mengandung tren linier, yang selanjutnya dapat dikonfirmasi dengan uji akar unit dengan uji Augmented Dickey-Fuller/ADF (yang menyatakan adanya akar unit) atau dengan plot ACF/PACF, seperti berikut:

Hipotesis Uji akar unit dengan uji Augmented Dickey-Fuller/ADF

$H_{0}: \rho=0$ (terdapat akar unit)

$H_{0}$ ditolak jika $\tau$ memiliki nilai kurang dari (lebih negatif) dari $\tau_{\alpha ; d b}$, namun karena $\tau$ memiliki nilai lebih dari (kurang negatif) dari $\tau_{\alpha ; d b}$ maka $H_{0}$ diterima. Terdapat akar unit yang menandakan bahwa data belum stasioner.

Uji ADF menunjukkan bahwa
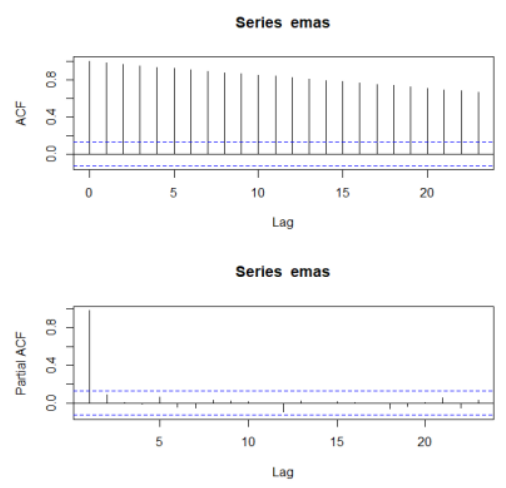

Gambar 3. Plot ACF dan PACF data harga emas dunia (Agustus 2000-Juli 2020)

hipotesis nol adanya akar unit dalam data (data tidak stasioner) diterima yang selanjutnya terkonfirmasi dari plot $\mathrm{ACF}$ yang meluruh secara lambat menuju nol.

Dengan demikian perlu dilakukan proses differencing dengan sebelumnya melakukan transformasi logaritma natural pada 240 data observasi harga emas dunia periode Agustus 2000 sampai dengan Juli 2020.

Gambar 4 berikut plot data hasil transformasi logaritma natural pada 240 data observasi harga emas dunia periode Agustus 2000 sampai dengan Juli 2020.

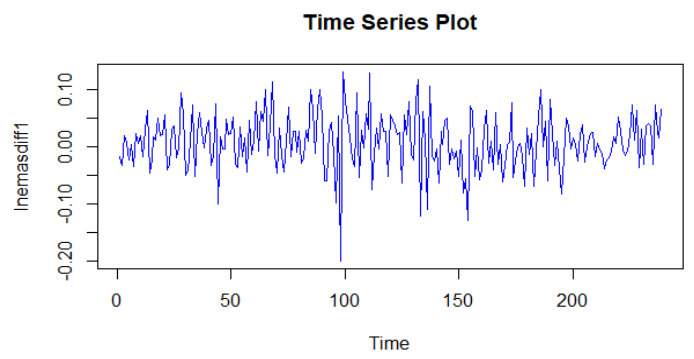

Gambar 4. Data hasil proses differencing logaritma natural harga emas dunia

Tabel 3. Hasil pengujian akar unit dengan uji Augmented Dickey-Fuller/ADF

\begin{tabular}{|l|c|l|l|l|l|}
\hline \multirow{2}{*}{ Data } & \multirow{2}{*}{$\boldsymbol{\tau}$} & \multicolumn{3}{|c|}{$\boldsymbol{\tau}_{\boldsymbol{\alpha} ; \boldsymbol{d b}}$} & \multirow{2}{*}{ Keputusan } \\
\cline { 3 - 6 } & & $\boldsymbol{\tau}_{\mathbf{0 , 0 1} \mathbf{2 2 4}}$ & $\boldsymbol{\tau}_{\mathbf{0 , 0 5} \mathbf{2 2 4}}$ & $\boldsymbol{\tau}_{\mathbf{0 , 1} \mathbf{2 2 4}}$ & \\
\hline $\begin{array}{l}\text { Harga emas dunia (Agustus 2000-Juli } \\
\text { 2020) }\end{array}$ & -1.7561 & -3.99 & -3.43 & -3.13 & Menerima $H_{0}$ \\
\hline
\end{tabular}

78 | Jurnal Aplikasi Statistika \& Komputasi Statistik V.12.1.2020, ISSN 2086-4132 
Tabel 4. Hasil pengujian akar unit dengan uji Augmented Dickey-Fuller/ADF

\begin{tabular}{|l|l|l|l|l|l|}
\hline \multirow{2}{*}{ Data } & \multirow{2}{*}{$\boldsymbol{\tau}$} & \multicolumn{3}{|c|}{$\boldsymbol{\tau}_{\boldsymbol{\alpha} ; \boldsymbol{d} \boldsymbol{b}}$} & \multirow{2}{*}{ Keputusan } \\
\cline { 3 - 6 } & & $\boldsymbol{\tau}_{\mathbf{0}, \mathbf{0 1} \mathbf{2 2 4}}$ & $\boldsymbol{\tau}_{\mathbf{0 , 0 5} \mathbf{2 2 4}}$ & $\boldsymbol{\tau}_{\mathbf{0 , 1} \mathbf{2 2 4}}$ & \\
\hline $\begin{array}{l}\text { Data hasil proses } \\
\text { differencing logaritma } \\
\text { natural harga emas } \\
\text { dunia }\end{array}$ & -5.4533 & -3.99 & & & \\
\end{tabular}

Tabel 5. Hasil Penaksiran dan Pengujian Signifikansi Parameter

\begin{tabular}{|c|c|c|c|c|c|}
\hline Model & Parameter & $\begin{array}{c}\text { SE } \\
\text { Parameter }\end{array}$ & $t_{\text {hitung }}$ & $\begin{array}{c}t_{\text {tabel }}= \\
=n-1 ; \alpha= \\
2,5 \%)\end{array}$ & Keputusan \\
\hline $\begin{array}{c}\text { ARIMA }(0,1,1) \\
\text { dengan } \\
\text { konstanta }\end{array}$ & $\hat{\theta}_{1}=-0,1377$ & 0.0662 & $-2,08006$ & $\begin{array}{c}-1,9810 \text { (digunakan - } \\
t_{\text {tabel }} \text { sebagai } \\
\text { pembanding) }\end{array}$ & $\begin{array}{c}\text { Menolak } \\
H_{0}\end{array}$ \\
\cline { 2 - 6 } & $\mu=0,0080$ & 0.0026 & 3,076923 & 1,9810 & $\begin{array}{c}\text { Menolak } \\
H_{0}\end{array}$ \\
\hline
\end{tabular}

Pada Gambar 4 terlihat bahwa data telah memenuhi asumsi kestasioneran data. Hal ini diperkuat dengan hasil uji akar unit dengan uji Augmented Dickey-Fuller/ADF sebagai berikut:

Hipotesis Uji akar unit dengan uji Augmented Dickey-Fuller/ADF

$H_{0}: \rho=0$ (terdapat akar unit)

$H_{0}$ ditolak jika $\tau$ memiliki nilai kurang dari (lebih negatif) dari $\tau_{\alpha ; d b}$. Nilai $\tau$ diatas memiliki nilai kurang dari (lebih negatif) dari $\tau_{\alpha ; d b}$ maka $H_{0}$ ditolak. Tidak terdapat akar unit yang menandakan bahwa data telah stasioner.
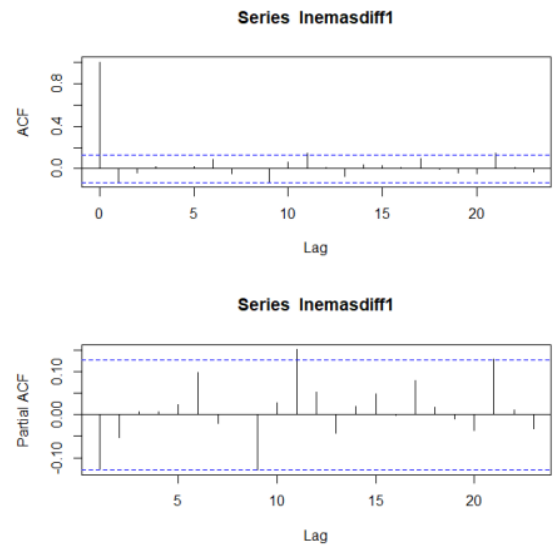

Gambar 5. Plot ACF dan PACF data hasil proses differencing logaritma natural harga emas dunia
Selanjutnya, proses identifikasi model ARIMA yang tepat untuk memodelkan data hasil proses differencing logaritma natural harga emas dunia sebagai berikut:

Pada Gambar 5(ACF) terlihat bahwa plot ACF signifikan pada lag ke-11 dan lag ke-21 dan Gambar 5(PACF) juga terlihat bahwa plot PACF signifikan pada lag ke-11 dan lag ke-21 sehingga model yang dicobakan pada data harga emas dunia adalah $\operatorname{ARIMA}(1,1,0), \quad \operatorname{ARIMA}(2,1,0)$, $\operatorname{ARIMA}(1,1,1), \quad \operatorname{ARIMA}(0,1,1) \quad$ dan $\operatorname{ARIMA}(0,1,2)$. Berdasarkan hasil estimasi parameter dan pengujian signifikansi parameter, diperoleh model dengan semua parameter yang signifikan disajikan pada tabel 5 dengan keterangan:

- $d f$ atau derajat bebas pada $t_{\text {tabel }}$ bernilai 238 sebab n pada model ini adalah 239. Banyak data harga emas dunia yang dipergunakan adalah 240 namun karena adanya proses differencing berakibat banyak data (n) menjadi 239 data.

- $t_{\text {tabel }}$ untuk $t(d f=238 ; \alpha=2,5 \%)$ tidak tertera pada tabel, namun dapat diperoleh melalui proses interpolasi.

$I=\frac{\text { range }_{\text {tvalue }}}{\text { range }_{d f}}($ current $d f-$ lowest $d f)$

Hasil interpolasi $=t \min -I$

Sehingga untuk memperoleh $t_{\text {tabel }}$ pada uji statistik diatas : 
$I=\frac{t_{d f=100 ; 0,025}-t_{d f=1000 ; 0,025}}{1000-100}(238-100)$

$I=\frac{1,984-1,962}{900} \times 138=0,003373333$

Hasil interpolasi $=1,984-0,003373333=$ $1,980626667 \sim 1,9810$

Berdasarkan Tabel 5, selanjutnya dilakukan pemeriksaan diagnostik yang meliputi uji white noise dan distribusi normal pada galat.
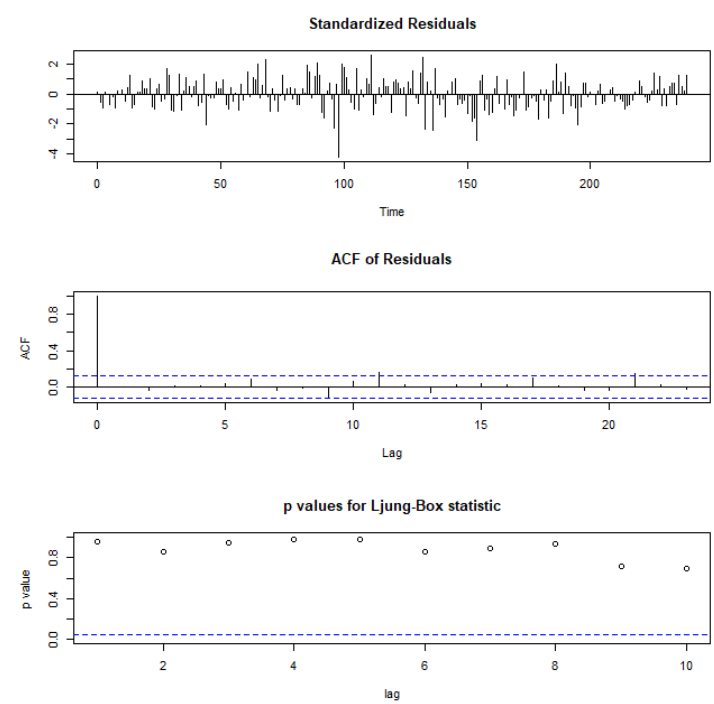

Gambar 6. Plot ACF galat dan p-values untuk Ljung Box statistic

Pada Gambar 6, plot ACF menunjukkan bahwa residual model sudah memenuhi model white noise karena bernilai di bawah 10\% (untuk lag lebih besar dari 1). Sedangkan nilai $p$-value Ljung-Box juga diatas garis batas $5 \%$, yang menandakan hipotesis nol residual tidak mengandung korelasi serial diterima.

Pada Tabel 6 terlihat bahwa Model $\operatorname{ARIMA}(0,1,1)$ lulus uji pada pemeriksaan diagnostik sebab galat yang dihasilkan pada model $\operatorname{ARIMA}(0,1,1)$ memenuhi asumsi white noise dan uji normalitas data. Artinya galat dari model $\operatorname{ARIMA}(0,1,1)$ merupakan model yang baik dari data harga emas dunia. Selanjutnya tidak dilakukan proses pemilihan model terbaik berdasarkan hasil perhitungan AIC maupun SBC dikarenakan hanya ada satu model yang lulus uji pemeriksaan diagnostik. Pengukuran ketepatan model dilakukan dengan perhitungan MAPE dihasilkan untuk model ARIMA $(0,1,1)$ adalah $3,70 \%$. Perhitungan MAPE menggunakan 240 data aktual yang dipergunakan dalam membangun model serta 240 data hasil prediksi yang diperoleh dari model (data tertera pada Lampiran 1).

Tabel 6. Pemeriksaan Diagnostik

\begin{tabular}{|l|l|l|}
\hline Tabel 6. & \multicolumn{2}{|l|}{ Pemeriksaan Diagnostik } \\
\hline Model & White noise & $\begin{array}{l}\text { Galat } \\
\text { berdistribusi } \\
\text { Normal }\end{array}$ \\
\hline $\begin{array}{l}\text { ARIMA } \\
(0,1,1) \\
\text { dengan } \\
\text { konstanta }\end{array}$ & Memenuhi & Normal \\
\hline
\end{tabular}

\section{Prediksi Model ARIMA}

Berdasarkan Tabel 3, model $\operatorname{ARIMA}(0,1,1)$ dengan konstanta jika dituliskan dalam bentuk persamaan diperoleh model sebagai berikut:

$$
\begin{aligned}
& (1-B) \hat{Y}_{t}=0,0081-0,1367 \varepsilon_{t-1} \\
& \text { dimana } \hat{Y}_{t}=\ln \hat{Z}_{t} \\
& \text { sehingga perhitungan nilai prediksi }
\end{aligned}
$$
untuk $Z_{t}$ adalah

\section{Keterangan:}

$$
\hat{Z}_{t}=\exp \left(\hat{Y}_{t}\right)
$$

$\hat{Z}_{t}$ : prediksi harga emas dunia

Pada Lampiran 1, ditampilkan hasil perhitungan nilai prediksi menggunakan

Tabel 7. Harga Emas Dunia (interval keyakinan 95\%)

\begin{tabular}{|cccc|}
\hline \multirow{2}{*}{ Waktu } & \multicolumn{3}{c|}{ Harga emas dunia (US\$/Troy ons) } \\
\cline { 2 - 4 } & Prediksi & Prediksi Terendah & Prediksi Tertinggi \\
\hline 1 Agustus 2020 & 1930,046 & 1758,346 & 2118,512 \\
\hline 1 September 2020 & 1945,651 & 1720,322 & 2200,491 \\
\hline 1 Oktober 2020 & 1961,381 & 1693,192 & 2272,050 \\
\hline 1 November 2020 & 1977,240 & 1672,146 & 2338,002 \\
\hline 1 Desember 2020 & 1993,227 & 1655,097 & 2400,434 \\
\hline 1 Januari 2021 & 2009,343 & 1640,923 & 2460,478 \\
\hline
\end{tabular}

80 | Jurnal Aplikasi Statistika \& Komputasi Statistik V.12.1.2020, ISSN 2086-4132 
model ARIMA $(0,1,1)$ untuk data in sample maupun data out sample.

Berikut adalah plot data harga emas dunia, nilai penyuaian in sample, serta nilai prediksi terendah dan prediksi tertinggi dengan interval keyakinan 95\% dengan model ARIMA $(0,1,1)$ di atas. Pada tabel 7 diperlihatkan hasil prediksi harga emas dunia per 1 Agustus 2020 hingga prediksi per 1 Januari 2021 mengalami kenaikan dengan rata-rata kenaikan sebesar 15,8594 US\$/Troy ons setiap bulannya.

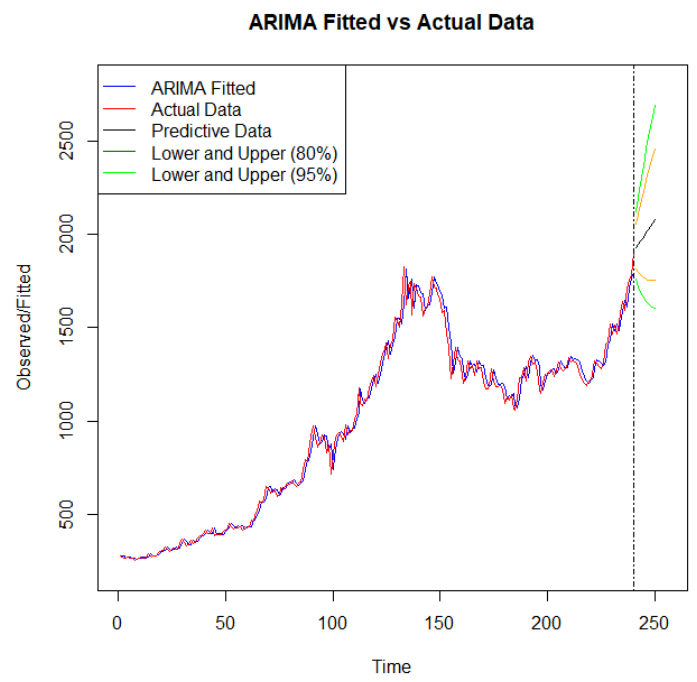

Gambar 6. Plot data harga emas dunia, runtun tersuai dan prediksi harga emas dunia

\section{KESIMPULAN DAN SARAN}

\section{Kesimpulan}

1. Model ARIMA $(0,1,1)$ dengan konstanta adalah model ARIMA terbaik untuk memodelkan data aktual harga emas dunia periode Agustus 2000-Juli 2020 dimana per Januari 2020 dunia telah dilanda pandemi Covid-19 sehingga model ini dapat dipergunakan untuk prediksi harga emas dunia di masa pandemi Covid-19. Adapun MAPE dari model ini adalah sebesar 3,70\%.

2. Model ARIMA $(0,1,1)$ dengan konstanta menghasilkan prediksi harga emas dunia per Agustus 2020 hingga Januari 2021 berturut-turut sebesar 1930,046; 1945,651; 1961,381; 1977,240; 1993,227; 2009,343. Rata-rata kenaikan harga emas dunia per bulannya selama periode ini (Agustus 2020 hingga Januari 2021) diperkirakan 15,8594 US $\$ /$ Troy ons emas

\section{Saran}

Berdasarkan hasil analisis menggunakan model prediksi ARIMA, saran yang diajukan peneliti untuk penelitian selanjutnya adalah:

1. Berdasarkan hasil penelitian ini diharapkan ada penelitian lanjutan yang mempergunakan model lainnya selain ARIMA yang dapat dipergunakan sebagai pembanding kesesuaian model untuk harga emas dunia.

2. Berdasarkan hasil prediksi harga emas dunia yang cenderung mengalami kenaikan (periode Agustus 2020 hingga Januari 2021), emas merupakan investasi yang aman dan menguntungkan di masa pandemi Covid-19.

\section{DAFTAR PUSTAKA}

Abdullah, L. (2012). ARIMA Model for Gold Bullion Coin Selling Prices Forecasting. International Journal of Advances in Applied Sciences, 1(4). https://doi.org/10.11591/ijaas.v1i4.14 95

Baker, S., Bloom, N., Davis, S., \& Terry, S. (2020). COVID-Induced Economic Uncertainty. National Bureau of Economic Research. https://doi.org/10.3386/w26983

Bandyopadhyay, G. (2016). Gold Price Forecasting Using ARIMA Model. Journal of Advanced Management Science, March, 117-121. https://doi.org/10.12720/joams.4.2.1 17-121

Fauziah, A., \& Surya, M. E. (2016). Peluang investasi emas jangka panjang melalui produk pembiayaan BSM cicil emas (studi pada bank syariah mandiri K.C. Purwokerto). Islamadina: Jurnal Pemikiran Islam, 16(1), 57-73.

Gujarati, D. N. (2004). Basic Econometric (4th ed.). The McGraw-Hill Companies.

Ji, Q., Zhang, D., \& Zhao, Y. (2020). Searching for safe-haven assets 
during the COVID-19 pandemic. International Review of Financial Analysis, $\quad$ 71(April), 101526. https://doi.org/10.1016/j.irfa.2020.10 1526

Rahmawati, Wahyuningsih, S., \& Syaripuddin. (2019). Peramalan laju produksi minyak bumi provinsi kalimantan timur menggunakan metode dca dan arima. Journal of Statistical Application and Computational Statistics, 11 No 1 , 73-86.

Rosadi, D. (2006). Pengantar Analisa Runtun Waktu. Universitas Gadjah Mada.

Rosadi, D. (2011). Analisis Ekonometrika\&Runtun Waktu Terapan dengan $R$. Penerbit ANDi. WHO. (2020a). Coronavirus. https://www.who.int/healthtopics/coronavirus\#tab=tab_1

WHO. (2020b). Coronavirus disease (COVID-19): Situation Report - 188. WHO, July. https://www.who.int/emergencies/dis eases/novel-coronavirus2019/situation-reports

Widarjono, A. (2007). Ekonometrika: Teori dan Aplikasi untuk Ekonomi dan Bisnis. Ekonisia.

Yulianti, N., \& Silvy, M. (2013). Sikap Pengelola Keuangan Dan Perilaku Perencanaan Investasi Keluarga Di Surabaya. Journal of Business and Banking, 3(1), 57-68. 


\section{LAMPIRAN}

Lampiran 1. Perbandingan Data Aktual dengan Data Prediksi Harga Emas Dunia In Sample

Data aktual harga emas dunia bulan Agustus 2000 - Juli 2020

\begin{tabular}{lrrrrrrrrrrrr}
\hline$[1]$ & 278,3 & 273,6 & 264,9 & 270,1 & 272,0 & 265,6 & 266,8 & 257,9 & 264,0 & 265,3 & 270,6 & 266,2 \\
{$[13]$} & 274,4 & 292,4 & 279,5 & 273,9 & 278,7 & 282,1 & 296,7 & 302,6 & 308,9 & 326,5 & 313,5 & 303,2 \\
{$[25]$} & 312,4 & 323,9 & 318,0 & 316,8 & 347,6 & 368,3 & 350,2 & 335,9 & 339,1 & 364,5 & 346,0 & 354,0 \\
{$[37]$} & 375,7 & 385,4 & 384,5 & 396,8 & 415,7 & 402,2 & 396,4 & 427,3 & 387,0 & 394,0 & 392,6 & 391,0 \\
{$[49]$} & 410,4 & 418,7 & 428,5 & 451,3 & 437,5 & 421,8 & 436,5 & 428,7 & 435,0 & 416,3 & 435,9 & 429,9 \\
{$[61]$} & 433,8 & 469,0 & 465,1 & 494,6 & 517,1 & 570,8 & 561,6 & 581,8 & 651,8 & 642,5 & 613,5 & 634,2 \\
{$[73]$} & 625,9 & 598,6 & 604,1 & 646,9 & 635,2 & 652,0 & 669,4 & 663,0 & 680,5 & 661,0 & 648,1 & 666,9 \\
{$[85]$} & 673,0 & 742,8 & 792,0 & 782,2 & 834,9 & 922,7 & 972,1 & 916,2 & 862,8 & 887,3 & 926,2 & 913,9 \\
{$[97]$} & 829,3 & 874,2 & 716,8 & 816,2 & 883,6 & 927,3 & 941,5 & 922,6 & 890,7 & 978,8 & 927,1 & 953,7 \\
{$[109]$} & 951,7 & $1.008,0$ & $1.039,7$ & $1.181,1$ & $1.095,2$ & $1.083,0$ & $1.118,3$ & $1.113,3$ & $1.180,1$ & $1.212,2$ & $1.245,5$ & $1.181,7$ \\
{$[121]$} & $1.248,3$ & $1.307,8$ & $1.357,1$ & $1.385,0$ & $1.421,1$ & $1.333,8$ & $1.409,3$ & $1.438,9$ & $1.556,0$ & $1.535,9$ & $1.502,3$ & $1.628,3$ \\
{$[133]$} & $1.828,5$ & $1.620,4$ & $1.724,2$ & $1.745,5$ & $1.565,8$ & $1.737,8$ & $1.709,9$ & $1.669,3$ & $1.663,4$ & $1.562,6$ & $1.603,5$ & $1.610,5$ \\
{$[145]$} & $1.684,6$ & $1.771,1$ & $1.717,5$ & $1.710,9$ & $1.674,8$ & $1.660,6$ & $1.577,7$ & $1.594,8$ & $1.472,2$ & $1.392,6$ & $1.223,8$ & $1.312,4$ \\
{$[157]$} & $1.396,1$ & $1.326,5$ & $1.323,6$ & $1.250,6$ & $1.201,9$ & $1.240,1$ & $1.321,4$ & $1.283,4$ & $1.295,6$ & $1.245,6$ & $1.321,8$ & $1.281,3$ \\
{$[169]$} & $1.285,8$ & $1.210,5$ & $1.171,1$ & $1.175,2$ & $1.183,9$ & $1.278,5$ & $1.212,6$ & $1.183,1$ & $1.183,5$ & $1.189,4$ & $1.172,1$ & $1.094,9$ \\
{$[181]$} & $1.131,6$ & $1.115,5$ & $1.141,5$ & $1.065,8$ & $1.060,3$ & $1.117,3$ & $1.233,9$ & $1.234,2$ & $1.289,2$ & $1.214,8$ & $1.318,4$ & $1.349,0$ \\
{$[193]$} & $1.306,9$ & $1.318,8$ & $1.271,5$ & $1.170,8$ & $1.150,0$ & $1.208,6$ & $1.252,6$ & $1.247,3$ & $1.266,1$ & $1.272,0$ & $1.240,7$ & $1.266,6$ \\
{$[205]$} & $1.316,2$ & $1.281,5$ & $1.267,0$ & $1.277,9$ & $1.306,3$ & $1.339,0$ & $1.315,5$ & $1.322,8$ & $1.316,2$ & $1.300,1$ & $1.251,3$ & $1.223,7$ \\
{$[217]$} & $1.200,3$ & $1.191,5$ & $1.212,3$ & $1.220,2$ & $1.284,7$ & $1.319,7$ & $1.312,8$ & $1.293,0$ & $1.282,8$ & $1.310,2$ & $1.409,7$ & $1.426,1$ \\
{$[229]$} & $1.519,1$ & $1.465,7$ & $1.511,4$ & $1.465,6$ & $1.520,0$ & $1.582,9$ & $1.642,5$ & $1.592,4$ & $1.713,4$ & $1.755,1$ & $1.781,2$ & $1.900,3$ \\
\hline
\end{tabular}

Data peramalan harga emas dunia bulan Agustus 2000 - Juli 2020

\begin{tabular}{lrrrrrrrrrrrr}
\hline$[1]$ & 276,7 & 280,5 & 276,7 & 268,6 & 272,1 & 274,2 & 268,9 & 269,2 & 261,5 & 265,8 & 267,5 & 272,3 \\
{$[13]$} & 269,2 & 275,9 & 292,4 & 283,5 & 277,4 & 280,8 & 284,2 & 297,3 & 304,3 & 310,7 & 326,9 & 317,9 \\
{$[25]$} & 307,6 & 314,3 & 325,2 & 321,5 & 320,0 & 346,4 & 368,1 & 355,5 & 341,3 & 342,1 & 364,2 & 351,3 \\
{$[37]$} & 356,5 & 376,0 & 387,2 & 388,0 & 398,8 & 416,7 & 407,4 & 401,1 & 427,0 & 395,4 & 397,4 & 396,4 \\
{$[49]$} & 394,9 & 411,5 & 421,1 & 430,9 & 452,0 & 443,0 & 428,1 & 438,8 & 433,5 & 438,3 & 422,6 & 437,5 \\
{$[61]$} & 434,4 & 437,4 & 468,3 & 469,3 & 495,0 & 518,1 & 567,8 & 567,0 & 584,4 & 647,2 & 648,3 & 623,2 \\
{$[73]$} & 637,8 & 632,6 & 608,0 & 609,5 & 646,8 & 641,9 & 655,8 & 672,9 & 669,7 & 684,5 & 669,5 & 656,3 \\
{$[85]$} & 670,8 & 678,1 & 739,4 & 790,9 & 789,7 & 835,2 & 917,5 & 972,2 & 931,2 & 878,9 & 893,3 & 929,0 \\
{$[97]$} & 923,3 & 848,4 & 877,6 & 743,0 & 812,2 & 880,4 & 928,1 & 947,2 & 933,4 & 903,7 & 975,9 & 941,2 \\
{$[109]$} & 959,6 & 960,5 & $1.009,4$ & $1.043,8$ & $1.170,5$ & $1.114,2$ & $1.096,0$ & $1.124,2$ & $1.123,8$ & $1.181,6$ & $1.217,7$ & $1.251,6$ \\
{$[121]$} & $1.200,7$ & $1.251,6$ & $1.310,4$ & $1.361,4$ & $1.392,9$ & $1.428,6$ & $1.357,3$ & $1.413,3$ & $1.446,9$ & $1.552,9$ & $1.550,6$ & $1.521,0$ \\
{$[133]$} & $1.626,1$ & $1.813,7$ & $1.659,0$ & $1.728,9$ & $1.757,2$ & $1.603,7$ & $1.732,5$ & $1.726,8$ & $1.690,6$ & $1.680,5$ & $1.591,1$ & $1.614,7$ \\
{$[145]$} & $1.624,1$ & $1.689,6$ & $1.773,8$ & $1.739,0$ & $1.728,6$ & $1.695,7$ & $1.678,8$ & $1.604,1$ & $1.608,9$ & $1.502,3$ & $1.418,6$ & $1.259,0$ \\
{$[157]$} & $1.315,4$ & $1.395,9$ & $1.346,6$ & $1.337,4$ & $1.272,4$ & $1.221,1$ & $1.247,4$ & $1.321,5$ & $1.299,0$ & $1.306,5$ & $1.263,9$ & $1.324,3$ \\
{$[169]$} & $1.297,5$ & $1.297,8$ & $1.232,0$ & $1.188,8$ & $1.186,5$ & $1.193,8$ & $1.276,7$ & $1.231,1$ & $1.199,2$ & $1.195,2$ & $1.199,8$ & $1.185,3$ \\
{$[181]$} & $1.115,9$ & $1.138,5$ & $1.127,7$ & $1.148,8$ & $1.085,5$ & $1.072,3$ & $1.119,9$ & $1.227,3$ & $1.243,2$ & $1.293,1$ & $1.235,2$ & $1.317,1$ \\
{$[193]$} & $1.355,4$ & $1.324,1$ & $1.330,1$ & $1.289,7$ & $1.196,1$ & $1.165,5$ & $1.212,3$ & $1.257,0$ & $1.258,7$ & $1.275,3$ & $1.282,7$ & $1.256,4$ \\
{$[205]$} & $1.275,4$ & $1.321,1$ & $1.297,2$ & $1.281,4$ & $1.288,7$ & $1.314,4$ & $1.346,3$ & $1.330,3$ & $1.334,5$ & $1.329,3$ & $1.314,6$ & $1.270,0$ \\
{$[217]$} & $1.239,9$ & $1.215,4$ & $1.204,4$ & $1.221,0$ & $1.230,1$ & $1.287,3$ & $1.325,8$ & $1.325,2$ & $1.307,8$ & $1.296,6$ & $1.318,9$ & $1.408,1$ \\
{$[229]$} & $1.435,1$ & $1.519,4$ & $1.484,8$ & $1.519,9$ & $1.484,8$ & $1.527,3$ & $1.587,8$ & $1.648,0$ & $1.612,8$ & $1.712,9$ & $1.763,3$ & $1.793,1$ \\
\hline
\end{tabular}


